\title{
Stress-related effects on reproductive capacity of pigs*
}

\author{
A. Madej ${ }^{1,4}$, M.T. Madsen ${ }^{2}$, Y. Brandt ${ }^{3}$, H. Kindahl ${ }^{3}$ and S. Einarsson ${ }^{3}$ \\ ${ }^{I} S L U$, Swedish University of Agricultural Sciences, \\ Department of Anatomy and Physiology \\ P.O. Box 7011, SE-750 07 Uppsala, Sweden \\ ${ }^{2}$ The National Committee for Pig Production, The Department for Nutrition and Reproduction \\ Axeltorv 3, DK-1609 Copenhagen V, Denmark \\ ${ }^{3} S L U$, Swedish University of Agricultural Sciences, \\ Department of Clinical Sciences \\ P.O. Box 7039, SE-750 07 Uppsala, Sweden
}

\begin{abstract}
Due to increased attention to welfare and changes in European legislation group-housing systems are becoming more used in several countries. Even though systems involving grouphousing of sows are in many ways very appealing, the effects of high stress levels during a short but critical phase of the reproductive cycle, e.g., resumption of ovarian activity, oestrus and ovulation, are yet to be clarified. The aim of the presentation is to review the research focusing on the possible factors, which may impair the reproductive processes of the pig.
\end{abstract}

KEY WORDS: stress, hormones, oestrus, pregnancy, pig

\section{INTRODUCTION}

Pig breeders in several European Union countries, i.e. Sweden and Denmark keep their sows in groups when they are not lactating. Compared to the system with crates for sows, the group housing system allows the sows to interact

\footnotetext{
* Supported by Swedish Farmers Foundation for Agricultural Research, FORMAS, Norma and Frode S. Jacobsens Foundation, Denmark and The National Committee for Pig Production, Denmark

${ }^{4}$ Corresponding author: e-mail: Andrzej.Madej@afys.slu.se
} 
socially and express behaviour that is more natural. However, there are also negative consequences of the group housing system. In newly formed groups, there will be fighting over rank order and in connection to feeding. High ranked sows in oestrus will mount submissive sows. This kind of interaction will give rise to periods of stress. Stress levels in a newly formed group of sows may persist for approximately two days until a ranking order is established among the animals (Tsuma et al., 1996), and even continue for additionally 10-12 days in large group of sows (Stookey and Gonyou, 1994). There are, however, different opinions about impairment of reproduction capacity of female pig during stress. Turner et al. (2005) concluded that repeated acute stress or acute or repeated acute elevations of cortisol are unlikely to disrupt reproduction in female pigs, even if this occurs during the series of endocrine events that induce oestrus and ovulation. Reproduction can be impaired by prolonged stress or the sustained elevation of cortisol for a substantial period. Even under such harsh conditions there are some individuals in which reproduction will not be impaired (Turner et al., 2005). In contrast, Kongsted (2004) described the impaired reproduction in group housed sows as a growing problem in many herds and this should be an indication for the necessities of further studies. Group housing conditions resulted in fewer born piglets per litter when comparing with individually housed sows (Fisker, 1995; Hansen, 2000). In group housed sows rebreeding was performed more often after an irregular oestrus-to-oestrus interval, i.e. 25-37 days than in sows kept in individual stalls, particularly during summer and autumn (Peltoniemi et al., 1999). The delayed onset of oestrus by $10 \mathrm{~h}$ after weaning in group housing sows was probably due to a delaying of the sequence of ovarian events (Langendijk et al., 2000). Additionally, Pedersen et al. (2003) reported that group housing may result in the impairment of heat detection and response to boar stimulation. Thus, the objective of this review is to present our research focusing on the effects of stress during a short but critical phase of the reproductive cycle, e.g., the resumption of ovarian activity after weaning, oestrus, ovulation, fertilization and the early embryo development.

\section{RELATIONSHIPS BETWEEN CRH, ACTH, CORTISOL, PROSTAGLANDIN $\mathrm{F}_{2 \alpha}$ METABOLITE AND PROGESTERONE}

It is well known the hypothalamic-pituitary-adrenal axis (HPA axis) is activated by stressful stimuli and is responsible for production of cortisol by the adrenal cortex. Adrenal stimulation induced by ACTH has been shown to elevate not only cortisol but also other hormones. Tsuma et al. (1998) reported that plasma cortisol and progesterone concentrations increased within $15 \mathrm{~min}$ after ACTH administration in the lactating sows. Progesterone concentrations increased to 
maximum levels of $3.7 \pm 1.0 \mathrm{nmol} / 1$ within $45 \mathrm{~min}$ after ACTH injection and returned to basal levels $(0.3-0.8 \mathrm{nmol} / 1) 75 \mathrm{~min}$ later. The other study demonstrated that administration of ACTH ( $10 \mu \mathrm{g} / \mathrm{kg}$ body weight) to ovariectomized gilts was followed by a concomitant elevation of cortisol, progesterone and prostaglandin $\mathrm{F}_{2 \alpha}$ metabolite but not oestradiol-17 $\beta$ levels in peripheral circulation (Mwanza et al., 2000b). Maximum concentrations of cortisol, progesterone and prostaglandin $\mathrm{F}_{2 \alpha}$ metabolite were reached 80,80 and $47 \mathrm{~min}$, respectively after administration of ACTH. The administration of ACTH to cycling gilts resulted in concomitant elevation of cortisol and prostaglandin $\mathrm{F}_{2 \alpha}$ metabolite with peak levels reached at 75 and 40 min, respectively (Madej et al., 2005b). The administration of ACTH to barrows resulted also in concomitant elevation of cortisol and prostaglandin $\mathrm{F}_{2 \alpha}$ metabolite with peak levels reached at 60 and $20 \mathrm{~min}$, respectively. Cortisol peak was seen at 20 min after administration of CRH to cycling gilts as well as barrows. Prostaglandin $\mathrm{F}_{2 \alpha}$ metabolite levels were not influenced after injection of $\mathrm{CRH}$ in cycling gilts and barrows (Madej et al., 2005b). It plausible to suggest that prostaglandin $\mathrm{F}_{2 \alpha}$ metabolite originated from $\mathrm{PGF}_{2 \alpha}$ synthesized in adrenal gland because feline and rat adrenocortical cells synthesize prostaglandins $\mathrm{F}_{2 \alpha}$ and $\mathrm{E}_{2}$ and that the total prostaglandins synthesis is stimulated by ACTH (Laychock and Rubin, 1977; Chanderbhan et al., 1979).

\section{SIMULATED STRESS BEFORE AND AFTER OVULATION}

Lang et al. (2003) reported that simulated stress during pro-oestrus by means of repeated injections of ACTH resulted in the prolongation of the oestrous cycle and a disturbance of follicular development in sows. The concentrations of cortisol as well as progesterone in jugular blood of the ACTH-group sows during the time of ACTH-injections before ovulation were significantly higher than of the controlgroup sows (Brandt et al., 2005a). These elevated concentrations of progesterone may interfere with the expected rise of progesterone after ovulation.

In addition, the administration of ACTH may also interfere with the transport of spermatozoa in the reproductive tract of sows (Brandt et al., 2005a). A majority of sows in the ACTH-group had moderately to exaggerated amounts of mucus in the intraluminal environment of the sperm reservoir (Brandt et al., 2005b). The mechanism behind this change in environment and the possible impact it might have on fertilization is unknown.

Food deprivation after ovulation was associated with an elevation of cortisol, progesterone and $\mathrm{PGF}_{2 \alpha}$ metabolite in peripheral circulation. There were also lower cleavage rate of the embryos and fewer viable spermatozoa in the reservoir (Mburu et al., 1998). It is interesting to notice that post-ovulatory food deprivation was associated with an altered activity of the oviduct and delay of ova transport 
(Mwanza et al., 2000a; Razdan et al., 2001) whereas repeated administration of ACTH had no such effects (Mwanza et al., 2000c; Razdan et al., 2002). On the other hand, repeated ACTH-injections resulted in a decrease of embryonic cleavage rate and number of spermatozoa attached to zona pellucida as well as in the rapid increase in $\mathrm{PGF}_{2 \alpha}$ metabolite (Razdan et al., 2002).

\section{SIMULATED STRESS DURING EARLY PREGNANCY}

The effect of glucocorticoid treatment on biochemical and hormonal parameters in early pregnant gilts was studied by Madej et al. (1977, 1998). Gilts were injected intramuscularly either with maize oil or hydrocortisone acetate $(250 \mathrm{mg})$ at $12-\mathrm{h}$ intervals from day 11 to day 20 of pregnancy. On days 34-36 of pregnancy, all gilts were slaughtered, and blood samples were collected. The treatment of early pregnant gilts with hydrocortisone acetate resulted in decreases of thyroxin $\left(\mathrm{T}_{4}\right)$ and increases in serum cholesterol, serum triglycerides and serum $\alpha_{2}$-globulin. The increase in triglycerides and cholesterol concentrations seen concomitant with a decrease in $\mathrm{T}_{4}$ concentrations after treatment with hydrocortisone in the present study suggests that there are some similarities in the response to chronic stress between pigs (Madej et al., 1997) and rats (Servatius et al., 1994). The findings of Wise et al. (1993) provide substantial evidence that pigs selected for high cholesterol concentrations had a lower ovulation rate, smaller litter size and heavier adrenal glands compared with pigs selected for low cholesterol concentrations. The elevation in $\alpha_{2}$-globulin concentrations found by us might indicate an alteration in homeostatic mechanisms in response to stress in pregnant pigs. This suggestion is in an agreement with finding of Lampreave et al. (1994) who reported that $\alpha_{2}$-globulin could be a major acutephase protein occurring during inflammation in the pig.

One of the obvious effects of hydrocortisone treatment was the delay of the first peak of oestrone sulphate occurring on day 13-14 of gestation in control gilts (Madej et al., 1998). Razdan et al. (2004) reported that in the control group, there was a significant increase in the blood plasma level of oestrone starting at day 19 of pregnancy, while the oestrone level in the ACTH-treated group did not start to increase until day 21 of pregnancy. Neither embryonic survival nor the numbers of viable foetuses were affected by the treatment applied.

An increase of progesterone during the stress situation may have different biological effects depending on the physiological status of the female pig. Elevated progesterone levels were seen during the time of food deprivation in early pregnant sows (Tsuma et al., 1996; Razdan et al., 2004). In both studies, no significant differences were found between control and treatment groups in embryonic/foetal survival rate. It is suggested that well-nursed sows appear to have the capacity to compensate for moderate stress induced around the time of maternal recognition of pregnancy. 
In our earlier study (Madej et al., 1996), we reported that the relative amount of IGF-II transcript in foetal tissues was increased both after dexamethasone and hydrocortisone treatment. This is in agreement with the findings of Price et al. (1992) who observed the increase of IGF-II transcript in livers of growth retarded rat foetuses whose mothers were treated with dexamethasone during the gestation period. Furthermore, Dell et al. (1997) found an effect of glucocorticoids on the activation of an embryonic IGF-II promoter in the mouse. The glucocorticoidinduced endocrine changes may be transient or persist into postnatal life with consequences for tissue growth and development both before and after birth. In the long term, prenatal glucocorticoid exposure can permanently reset endocrine systems, such as the somatotrophic and hypothalamic-pituitary-adrenal axes, which, in turn, may contribute to the pathogenesis of adult disease (Fowden and Forehead, 2004).

\section{IS MATING LESS STRESSFUL THAN ARTIFICIAL INSEMINATION?}

At mating as well as during artificial insemination (AI) semen is deposited into uterus of pigs. Semen transport from cervix to the uterine horn is possible due to gravitational force and uterine contraction (Scott, 2000). In an elegant study, Langendijk et al. (2002) demonstrated that both suppression and stimulation of uterine contractility adversely affect fertilization in sows. The same group (Langendijk et al., 2003) reported that the presence of the boar induced the release of oxytocin and clearly increased the myometrial activity in sows. It seems that mating of sows results in a higher litter size than AI (Tummaruk et al., 2000). Multiparous sows in a Danish experimental station were mated or inseminated during the first oestrus after weaning (Madsen et al., 2002; Madej et al., 2005a). Sows had the possibility of nose-to-nose contact with a boar during the whole trial. Mating resulted in a significant elevation in peripheral plasma concentrations of oxytocin within 10 min without any significant changes in $\mathrm{PGF}_{2 \alpha}$ metabolite. In contrast, in inseminated sows we observed significant increase in $\mathrm{PGF}_{2 \alpha}$ metabolite within 10-40 min without any changes in oxytocin secretion. In this experiment, sows were housed in crates. In the second experiment when sows were only inseminated and housed in crates cortisol and $\mathrm{PGF}_{2 \alpha}$ metabolite were measured in the blood plasma. There was a dramatic and significant increase in $\mathrm{PGF}_{2 \alpha}$ metabolite with its maximum concentration $21 \mathrm{~min}$ after AI. A significant increase in cortisol concentrations reached maximum $12 \mathrm{~min}$ after AI. It is interesting to note that the maximum concentrations of cortisol was seen before PGF $_{2 \alpha}$ metabolite (Madej et al., 2005a). This is in contrast to our previous study where it was demonstrated that ACTH stimulates the secretion of $\mathrm{PGF}_{2 \alpha}$ earlier than cortisol in ovariectomized and cycling gilts (Mwanza et al., 2000b; Madej et al., 2005b). 


\section{CONCLUSIONS}

Simulated stress induced by injections of ACTH during standing oestrus results in elevated concentrations of progesterone before ovulation and may interfere with the rise of progesterone after ovulation. ACTH-injections may also interfere with the transport of spermatozoa through the female genital tract of pigs. Exogenous $\mathrm{ACTH}$ in sows may also alter the intraluminal environment of the sperm reservoir. It is interesting to note that simulated stress during prooestrus causes a prolongation of the oestrous cycle and it disturbs the follicular development. The results indicate that progesterone might be a good alternative to cortisol for assessing stress in sows during oestrus. On the other hand an extra post-ovulatory increase of progesterone during stress-related situations might be helpful for the embryo survival.

Mating caused an elevation of oxytocin, while artificial insemination stimulated an increase of $\mathrm{PGF}_{2 \alpha}$ metabolite in sows. The question is to find out the reason for this difference and to explain whether $\mathrm{PGF}_{2 \alpha}$ has negative or positive effect on the ovarian function and in consequence the reproductive performance of sows.

Even though systems involving group-housing of sows are in many ways very appealing, the effects of high stress levels during a short but critical phase of the reproductive cycle, e.g., resumption of ovarian activity, oestrus and ovulation, are yet to be clarified.

\section{REFERENCES}

Brandt Y., Lang A., Madej A., Rodriguez-Martinez H., Einarsson S., 2005a. Impact of ACTH administration on the oviductal sperm reservoir in sows: The local endocrine environment and distribution of spermatozoa. Anim. Reprod. Sci. (in press)

Brandt Y., Lang A., Madej A., Rodriguez-Martinez H., Einarsson S., 2005b. Impact of ACTH during oestrus on the postovulatory ultrastructure of the spermatozoa and their environment in the tubal reservoir of the sow (submitted)

Chanderbhan R., Hodges V.A., Treadwell C.R., Vahouny G.V., 1979. Prostaglandin synthesis in rat adrenocortical cells. J. Lipid Res. 20, 116-124

Dell G., Ward A., Engström W., 1997. Regulation of a promoter from the mouse insulin like growth factor II gene by glucocorticoids. FEBS Lett. 419, 161-165

Fisker B.N., 1995. Management procedures for group housing of pregnant sows (in Danish). Landsudvalget for Svin. Den rullende Afprøvning Meddelelse 311, 1-7

Fowden A.L., Forhead A.J., 2004. Endocrine mechanisms of intrauterine programming. Reproduction 127, 515-526

Hansen L.U., 2000. Mating stables for individually and group housed sows (in Danish). Den rullende Afprøvning Meddelelse 6, 1-6

Kongsted A.G., 2004. Stress and fear as possible mediations of reproduction problems in group housed sows. A review. Acta Agr. Scand., Sect. A, Anim. Sci. 54, 58-66

Lampreave F., González-Ramón N., Martínez-Ayensa S., Hernandez M.A., Lorenzo H.K., GarcíaGil A., Piñeiro A., 1994. Characterization of the acute phase serum protein response in pigs. Electrophoresis 15, 672-676 
Lang A., Kaeoket K., Kindahl H., Madej A., Einarsson S., 2004. Influence of CRH and ACTH administration on endocrine profile and ovulation in sows. Reprod. Domest. Anim. 39, 181-189

Langendijk P., Bouwman E.G., Kidson A., Kirkwood R.N., Soede N.M., Kemp B., 2002. Role myometrial activity in sperm transport through the genital tract and in fertilization in sows. Reproduction 123, 683-690

Langendijk P., Bouwman E.G., Schams D., Soede N.M., Kemp B., 2003. Effects of different stimuli on oxytocin release, uterine activity and receptive behaviour in estrous sows. Theriogenology $59,849-861$

Langendijk P., Soede N.M., Kemp B., 2000. Effects of boar contact and housing conditions on estrus expression in weaned sows. J. Anim. Sci. 78, 871-878

Laychock S.G., Rubin R.P., 1975. ACTH-induced prostaglandin biosynthesis from 3H-arachidonic acid by adrenocorticla cells. Prostaglandins 10, 529-540

Madej A., Einarsson S., Romanowicz K., Forsberg M., Tsuma V.T., Engström W., Barcikowski B., 1996. Simulated stress and the biochemical, endocrine and reproductive consequences in the pig. Reprod. Domest. Anim. 31, 565-569

Madej A., Lang A., Brandt Y., Kindahl H., Madsen M.T., Einarsson S., 2005a. Factors regulating ovarian function in pigs. Domest. Anim. Endocrinol. (in press)

Madej A., Mwanza A.M., Kindahl H., Einarsson S., 2005b. Effect of ACTH and CRH on plasma levels of cortisol and prostaglandin $\mathrm{F}_{2 \alpha}$ in cycling gilts and castrated boars (submitted)

Madej A., Romanowicz K., Einarsson S., Forsberg M., Barcikowski B., 1997. The effect of glucocorticoid treatment on biochemical and hormonal blood parameters in early pregnant gilts. Acta Vet. Scand. 38, 263-273

Madej A., Romanowicz K., Einarsson S., Forsberg M., Barcikowski B., 1998. Urinary excretion of oestrone sulphate and cortisol in early pregnant gilts treated with glucocorticoids. Acta Vet. Scand. 39, 61-70

Madsen M.T., Larsen M., Mathiasen J., Kindahl H., Einarsson S., Madej A., 2002. Plasma levels of oxytocin and $\mathrm{PGF}_{2 \alpha}$ metabolite during AI and mating in multiparous sows. Reprod. Domest. Anim. 37, 242

Mburu J.N., Einarsson S., Kindahl H., Madej A., Rodriguez-Martinez H., 1998. Post-ovulatory influence of food deprivation on embryo development, oviductal sperm concentration and hormonal profiles in the pig. Anim. Reprod. Sci. 52, 221-234

Mwanza A.M., Englund P., Kindahl H., Lundeheim N., Einarsson S., 2000a. Effects of postovulatory food deprivation on the hormonal profiles, activity of the oviduct and ova transport in sows Anim. Reprod. Sci. 59, 185-199

Mwanza A.M., Madej A., Kindahl H., Lundeheim N., Einarsson S., 2000b. Plasma levels of cortisol, progesterone, oestradiol-17 $\beta$ and prostaglandin $\mathrm{F}_{2 \alpha}$ metabolite after ACTH (Synacthen Depot ${ }^{\circledR}$ ) administration in ovariectomized gilts. J. Vet. Med. A 47, 193-200

Mwanza A.M., Madej A., Kindahl H., Lundeheim N., Einarsson S., 2000c. Postovulatory effect of repeated administration of ACTH (Synacthen Depot ${ }^{\circledR}$ ) on the contractile activity of the oviduct, ova transport and endocrine status of recently ovulated and unrestrained sows. Theriogenology 54, 1305-1316

Pedersen L.J., Heiskanen T., Damm B.I., 2003. Sexual motivation in relation to social rank in pairhoused sows. Anim. Reprod. Sci. 75, 39-53

Price W.A., Stiles A.D., Moats-Staats B.M., d'Ercole A.J., 1992. Gene expression of insulin like growth factors (IGFs), the type 1 IGF receptor and IGF binding proteins in dexamethasone induced fetal growth retardation. Endocrinology 130, 1424-1432

Razdan P., Mwanza A.M., Kindahl H., Hultén F., Einarsson S., 2001. Impact of postovulatory food deprivation on ova transport, hormonal profiles and metabolic changes in sows. Acta Vet. Scand. $42,45-55$ 
Razdan P., Mwanza A.M., Kindahl H., Rodriguez-Martinez H., Hultén F., Einarsson S., 2002. Effect of repeated ACTH-stimulation on early embryonic development and hormonal profiles in sows. Anim. Reprod. Sci. 70, 127-137

Razdan P., Tummaruk P., Kindahl H., Rodriguez-Martinez H., Hultén F., Einarsson S., 2004. Hormonal profiles and embryo survival of sows subjected to induced stress during days 13 and 14 of pregnancy. Anim. Reprod. Sci. 81, 295-312

Scott M.A., 2000. A glimpse at sperm function in vivo: sperm transport and epithelial interaction in female reproductive tract. Anim. Reprod. Sci. 60-61, 337-348

Servatius R.J., Ottenweller J.E., Natelson B.H., 1994. A comparison of the effects of repeated stressor exposures and corticosterone injections on plasma cholesterol, thyroid hormones and corticosterone levels in rats. Life Sci. 55, 1611-1617

Stookey J.M., Gonyou H.W., 1994. The effects of regrouping on behavioral and production parameters in finishing swine. J. Anim. Sci. 72, 2804-2811

Tsuma V.T., Einarsson S., Madej A., Kindahl H., Lundeheim N., 1996. Effect of food deprivation during early pregnancy on endocrine changes in primiparous sows. Anim. Reprod. Sci. 41, 267-278

Tummaruk P.P., Lundeheim N., Einarsson S., Dalin A.-M., 2000. Reproductive performance of purebred Swedish Landrace and Swedish Yorkshire Sows: II. Effect of mating type, weaningto-first-service interval and lactation length. Acta Agr. Scand., Sect. A, Anim. Sci. 50, 217-224

Turner A.I., Hemsworth P.H., Tilbrook A.J., 2005. Susceptibility of reproduction in female pigs to impairment by stress or elevation of cortisol. Domest. Anim. Endocrinol. (in press)

Wise T., Young L.D., Pond W.G., 1993. Reproductive, endocrine, and organ weight differences of swine selected for high or low serum cholesterol. J. Anim. Sci. 71, 2732-2738

\section{STRESZCZENIE}

\section{Wpływ stresu na zdolności rozrodcze u świń}

W związku ze zwiększającym się zainteresowaniem nad dobrostanem zwierząt i zmianami w legislacji europejskiej, systemy grupowego utrzymania zwierząt są częściej stosowane w wielu krajach. Chociaż systemy grupowego utrzymania loch są w wielu przypadkach bardzo interesujące, wpływ wysokiego poziomu stresu w czasie krótkiej, ale krytycznej fazie cyklu reprodukcyjnego, np. początek aktywności jajnikowej, ruja i owulacja, nie jest wystarczająco znany. W pracy przedstawiono wyniki badań ukierunkowanych na czynniki mogące niekorzystnie wpływać na procesy rozrodcze u świni. 